\title{
Research of the somatic health of student youth using information and communication technologies
}

\author{
Oksana Gorna*, Tatiana Stanishevska, Tatiana Kopulova, Olga Yusupova, and Daria Horban
}

Bogdan Khmelnitsky Melitopol State Pedagogical University, Department of Anatomy and Physiology of Man and Animals, Melitopol, 72312, Ukraine

\begin{abstract}
The article is devoted to the issues of using information-communication technologies for monitoring the physical health of students, which will enable them to be more successful, adaptable to the environment and current social changes in the future. The study included determining the level of somatic health by the method of G. L. Apanasenko. The rapid assessment had a fairly wide range of individual indicators of overall health, as well as cardiovascular and respiratory system functionality. The analysis of the conducted studies clearly indicates the need for constant monitoring of the indicators of physical development and somatic health of students throughout the study period. In order to objectively evaluate somatic health and to track it in dynamics, the students proposed the information and communication technology "Health Portfolio" developed by the authors. The implementation of such monitoring model and information program provides an automated assessment of the functionality of the human body and is accurate, informative and physiologically sound. Due to the increase in the amount of all kinds of information, as a pledge of future professional success of modern students, there is a problem of motivation of healthy lifestyle and involvement of students in independent motor activity.
\end{abstract}

\section{Introduction}

With environmental degradation, poor nutrition, sedentary lifestyles, the risk of deteriorating of overall health state increases. This set of negative factors eventually leads to the fact that the available functional reserves of the organism become insufficient to adequately respond to external influences of different nature $[1,2,3]$.

Motor activity is an essential component of a healthy lifestyle and one of the ways to form, maintain and promote health. Physical activity has a stimulating effect on almost all life support systems. Due to the growing flow of information, the constant use of computer and digital technologies in education and everyday life has led to a restriction of motor activity. Since motor activity is an effective method for the prevention of cardiovascular pathology, metabolic disorders, diseases of the musculoskeletal system, the question arises of the need to monitor the state of health and reserve capacity of the body nature $[2,4,5,6]$.

Despite a large number of studies $[2,6,7,8]$ devoted to studying the health status of students, the physical abilities of their body, there is a shortage of express ICT methods for assessing and introspecting an individual's somatic health. In connection with the foregoing, the aim of the study is a comparative analysis of the somatic health of students with different levels of motor activity.

In connection with the above data, the aim of the study was to analyze the somatic health of students and develop a monitoring model for evaluating the functional capabilities of an organism.

\section{Results and discussions}

To consider the external and internal factors affecting the quality of life of students, the components of the students' lifestyle were studied.

When assessing the state of health of respondents using the self-assessment method, it was found that $54.30 \%$ of female students and $67.20 \%$ of male students rate it positively (Fig. 1).

In the minds of students, such concepts as "youth" and "health" are inseparable. Obviously, therefore, quite optimistic outlook on the state of their health, the level of personal physical culture is inherent in students $[2,4]$.

Based on the data obtained by us, it follows that students represent a category of the population with increased risk factors, which include nervous and mental strain, constant disturbances in diet, labor and rest.

In the lifestyle of students, there is often a lack of health care: disorder, randomness, expressed in untimely food intake, systematic lack of sleep, a short stay in the fresh air and lack of motor activity.

The index of motor activity of students was determined by the method of O. S. Kuts [9]. The standard of change in motor activity was the weekly index of motor activity (IMA). Scales were used to obtain reliable and objective results in the study, followed by grouping of all types of movements. The first group includes daily 
movements, and the second group includes exercises related to physical training and sports. The results obtained were processed using the following formula:

$$
I M A=\left(\sum H M A+\sum P A\right) / T_{T} \times 100 \%
$$

where IMA is the index of motor activity per week (\%);

$T_{T}$ - time of activity;

$\Sigma H M A$ - the amount of time spent on household movements (min);

$\Sigma P A$ - the amount of time spent on exercise and sports (min) [8].
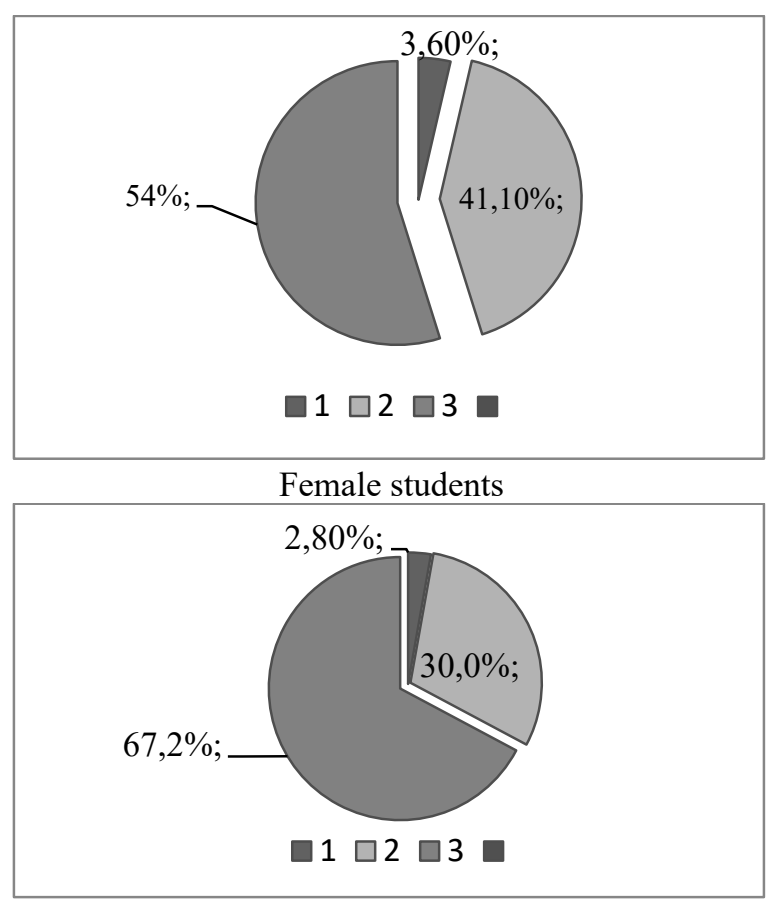

Male students

Fig. 1. The results of self-esteem of their health by students: 1 - significant deviations in health state; 2 - minor deviations in health state; 3 - no complaints, almost healthy.

According to the results of the conducted questionnaire of general and physical-fitness motor activity, the time spent by students on active exercise of physical tasks is insufficient, and they belong to the group of people with low level of physical activity. The analysis of the answers showed that male students spend on average $3,42 \pm 0,07 \%$ of time per week for daily physical activity, and female students spend $2,39 \pm 0,05 \%$ of time for physical motor activity. The weekly motor activity index was $5,81 \pm 0,14 \%$ and had no significant differences between the sexes.

Assessment of the somatic health of students was carried out according to the method of G. L. Apanasenko, which characterizes the main indicators of body functions: the heart rate at rest, the time to restore the heart rate to its original level after 20 squats in $30 \mathrm{sec}$.; growth, body weight, vital lung capacity (VC), hand dynamometry, blood pressure $[4,6,10]$. The choice of this method is due to the fact that it allows to comprehensively determine the functional state of the organism according to the indicators of the cardio-respiratory and muscular system, which are formalized in quantitative units (points) and are related to the level of individual health (Table 1). This technique consists of determining anthropometric and functional indicators and their indices.

Table 1. Level of indicator of mass-height (Quetelet index) of students, $\%$.

\begin{tabular}{|c|c|c|c|c|c|c|}
\hline \multirow{2}{*}{ Sex } & \multirow{2}{*}{ Age } & \multicolumn{5}{|c|}{ Indicator Level } \\
\cline { 3 - 8 } & & Low & $\begin{array}{c}\text { Below the } \\
\text { average }\end{array}$ & Average & $\begin{array}{c}\text { Above the } \\
\text { average }\end{array}$ & High \\
\hline \multirow{4}{*}{ Male } & $17-18$ & - & 1,7 & 36,8 & - & - \\
\cline { 2 - 8 } & $19-20$ & 0,8 & 0,8 & 31,8 & - & - \\
\cline { 2 - 8 } & $21-22$ & 0,8 & 1,7 & 25,8 & - & - \\
\hline \multicolumn{2}{|c|}{ Total } & 1,6 & 4 & 94,4 & - & - \\
\hline \multirow{3}{*}{ Female } & $17-18$ & 0,8 & 5,3 & 30 & - & - \\
\cline { 2 - 8 } & $19-20$ & 2,3 & 3,9 & 28,4 & - & - \\
\cline { 2 - 8 } & $21-22$ & - & 3,9 & 25,4 & - & - \\
\hline \multicolumn{2}{|c|}{ Total } & 3,1 & 13,1 & 83,8 & - & - \\
\hline
\end{tabular}

The basis of the developed system is based on the indicators of physical development (height, body weight, vital capacity of the lungs, wrist dynamometry), the state of the cardiovascular system at rest and in the recovery period after dosed physical activity. Express assessment is based on the relationship between overall endurance, the volume of physiological reserves and the manifestation of economization of the function of the cardiorespiratory system $[4,6,7]$.

Mass-height index (Quetelet index), showing the ratio of body weight to growth was determined by the formula:

$$
Q I=M / R
$$

where: $Q I-$ Quetelet index;

$M$ - body weight $(\mathrm{g})$;

$R$ - height (cm)

According to the indicators of mass-height ratio, the average level of this indicator among male and female students prevailed. This indicates that they do not have defects with body proportions, and the rest of students have marked deviation of this indicator in the direction of increasing or decreasing weight in accordance with physiological norms.

Thanks to the data obtained, the life index (LI) was calculated, showing the extent of oxygen which lungs can provide the whole body when it is in active motion. Life index according to Apanasenko is determined by dividing VCL $(\mathrm{ml})$ by body weight $(\mathrm{kg})$, i.e. which lung volume accounts for $1 \mathrm{~kg}$ of body weight $[4,6]$ :

$$
L I=V C L / M
$$

where: $L I$ is the life index $(\mathrm{ml} / \mathrm{kg})$;

$V C L$ - vital lung capacity $(\mathrm{ml})$;

$M$ - body weight (kg).

So, the greater the body weight of a person, the higher the need for its tissues in oxygen, the more effective the lungs should be to ensure adequate ventilation in normal conditions. Accordingly, under increased load, these needs will increase many times over.

The life index is an important indicator of the quantitative expression of students' health, as it is an informative indicator of the conformity of external respiration and weight with the relevant norm [6]. 
The indicators of life index show that there are slight differences between boys and girls. Thus, among the students studied, the average life index values were $31,7 \%$ of boys and $26,9 \%$ of girls. However, there were a higher number of girls who had below the average and high indicators of life index (37.5 and 1.5\% respectively), while boys did not have high indicators and only $11.5 \%$ of male students had indicators of life index at levels higher than average. At the same time, 30\% of low-score students had insufficient pulmonary ventilation (Table 2).

Table 2. Comparative characteristics of students' indicators of life index, $\%$.

\begin{tabular}{|c|c|c|c|c|c|c|}
\hline \multirow{2}{*}{ Sex } & \multirow{2}{*}{ Age } & \multicolumn{5}{|c|}{ Indicator Level } \\
\cline { 3 - 8 } & & Low & $\begin{array}{c}\text { Below the } \\
\text { average }\end{array}$ & Average & $\begin{array}{c}\text { Above the } \\
\text { average }\end{array}$ & High \\
\hline \multirow{3}{*}{ Male } & $17-18$ & 13,4 & 8,3 & 12,5 & 4,1 & - \\
\cline { 2 - 7 } & $19-20$ & 13,4 & 5,8 & 10 & 4,1 & - \\
\cline { 2 - 7 } & $21-22$ & 9,2 & 6,7 & 9,2 & 3,3 & - \\
\hline \multicolumn{2}{|c|}{ Total } & 36 & 20,8 & 31,7 & 11,5 & - \\
\hline \multirow{3}{*}{ Female } & $17-18$ & 2,3 & 9,2 & 7,7 & 15,3 & 1,5 \\
\cline { 2 - 7 } & $19-20$ & 5 & 7,7 & 9,2 & 13 & - \\
\cline { 2 - 7 } & $21-22$ & 3 & 6,9 & 10 & 9,2 & - \\
\hline \multicolumn{2}{|c|}{ Total } & 10,3 & 23,8 & 26,9 & 37,5 & 1,5 \\
\hline
\end{tabular}

Power index is required for qualitative assessment of muscle strength. Muscle strength means the ability of muscles to overcome external resistance or counteract it through muscular effort. Muscle strength is manifested in three main forms: maximum muscle strength (depends on the number and thickness of the muscle fibers), highspeed force and endurance.

Measurement of the strength of the hand (wrist dynamometer) was performed using a wrist dynamometer. The power index is the percentage of the muscle strength of the hand to body weight. Thanks to the data obtained, the power index (PI) was calculated by the formula:

$$
P I=H P / M
$$

where: $P I-$ power index $(\mathrm{kg})$;

$H P$ - hand power $(\mathrm{kg})$;

$M$ - body weight (kg).

Analyzing the indicators of wrist dynamometry, it should be noted that in young men the initial level of hand power on the right and left arm was not significantly different. The same trend is observed in girls. The analysis of physical development showed that the range of distribution of morphological indicators in them is quite wide. Calculating the power index, we noticed that most of the students studied were characterized by low and below average levels (Table 3 ).

Thus, in young men, this figure was $35,0 \%-$ a low level and 30,0\% - below the average level. Girls showed a tendency to improve $-38,3 \%$ of the respondents had above average and high level of the power index.

Thus, among all the investigated, the high level of the power index was determined only at $12,6 \%$, the low level $-48,0 \%$ (Fig. 2).

The Robinson index characterizes the functional state of the cardiovascular system.

$$
I R=R H R \times A T_{\max } / 100
$$

where: $I P$ - Robinson Index;

$R H R$ - resting heart rate (beats / $\mathrm{min}$ );

$A T_{\max }$ - maximum blood pressure (mm of mercury).

Table 3. Level of indicators of the power index of students, $\%$.

\begin{tabular}{|c|c|c|c|c|c|c|}
\hline \multirow{2}{*}{ Sex } & \multirow{2}{*}{ Age } & \multicolumn{5}{|c|}{ Indicator Level } \\
\cline { 3 - 7 } & Low & $\begin{array}{c}\text { Below the } \\
\text { average }\end{array}$ & Average & $\begin{array}{c}\text { Above the } \\
\text { average }\end{array}$ & High \\
\hline \multirow{3}{*}{ Male } & $17-18$ & 20 & 5,8 & 9,1 & 6,8 & 1,7 \\
\cline { 2 - 7 } & $19-20$ & 20,8 & 1,7 & 4,2 & 4,2 & 0,8 \\
\cline { 2 - 7 } & $21-22$ & 18,4 & 3,3 & 5,8 & 1,6 & 0,8 \\
\hline \multicolumn{2}{|c|}{ Total } & 35,0 & 30,0 & 19,1 & 12,6 & 3,3 \\
\hline \multirow{5}{*}{ Female } & $17-18$ & 3,8 & 17,7 & 6,2 & 5,4 & 3,1 \\
\cline { 2 - 7 } & $19-20$ & 5,4 & 18,5 & 3,8 & 2,3 & 4,6 \\
\cline { 2 - 7 } & $21-22$ & 3,8 & 16,2 & 3,1 & 4,6 & 1,6 \\
\hline \multicolumn{2}{|c|}{ Total } & 13 & 52,4 & 13 & 12,3 & 9,3 \\
\hline
\end{tabular}
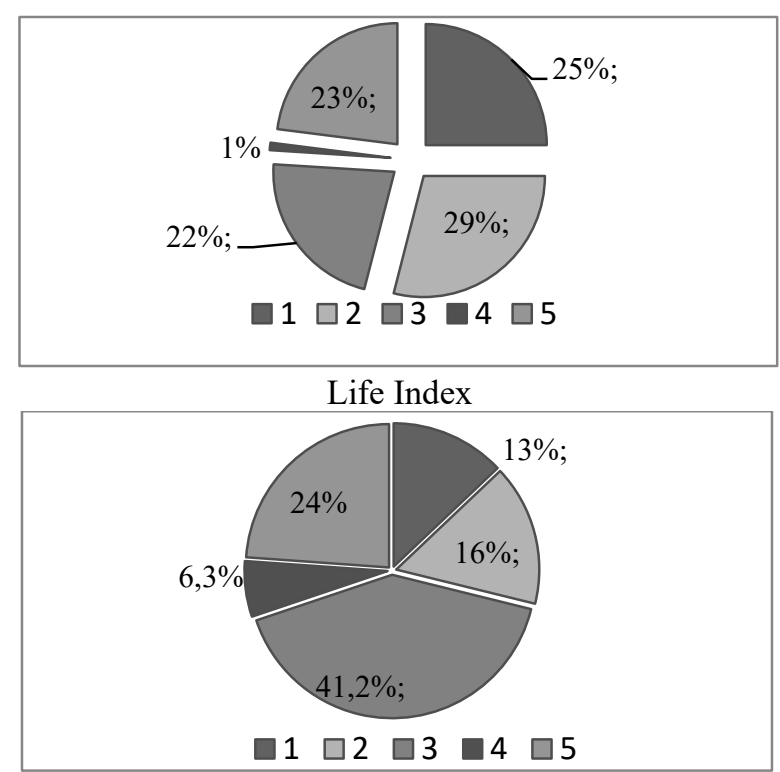

Power Index

Fig. 2. Robinson index indicator and Ruffier index indicator by students: 1 - above the average level; 2 - the average level; 3 below the average level; 4 - high level; 5 - low level.

A low Robinson index score indicates a violation of cardiovascular activity. A high Robinson index at rest may indicate low aerobic capacity of the body and therefore low somatic health $[2,4]$.

The average of the Robinson index was observed in $53,3 \%$ of boys and $63,8 \%$ of girls. In other physiological indicators of the functional state of the cardiovascular system of the organism indicate the general pattern of change in the state of regulatory systems, which demonstrate the tension of adaptive mechanisms, which should be taken into account when analyzing exercise programs with this contingent (Table 4).

Thus, the high and low level of the Robinson index was not found in the studied students, above the average $26,0 \%$, the average $-58,5 \%$, below the average $-15,5 \%$ of the studied students (Fig. 3).

The Ruffier Index shows the recovery time to the "normal rhythm" after increased heart rate and characterizes the magnitude of the performance reserve. 
The higher this reserve, the less time it takes for the heart to recover its original working rhythm after a high load [4, 5] (Table 5).

Table 4. The value of the Robinson index, $\%$.

\begin{tabular}{|c|c|c|c|c|c|c|}
\hline \multirow{2}{*}{ Sex } & \multirow{2}{*}{ Age } & \multicolumn{5}{|c|}{ Indicator Level } \\
\cline { 3 - 8 } & & Low & $\begin{array}{c}\text { Below the } \\
\text { average }\end{array}$ & Average & $\begin{array}{c}\text { Above the } \\
\text { average }\end{array}$ & High \\
\hline \multirow{3}{*}{ Male } & $17-18$ & - & 4,2 & 20 & 14,2 & - \\
\cline { 2 - 7 } & $19-20$ & - & 6,7 & 15 & 11,6 & - \\
\cline { 2 - 7 } & $21-22$ & - & 2,5 & 18,3 & 7,5 & - \\
\hline \multicolumn{2}{|c|}{ Total } & - & - & 53,3 & 33,3 & - \\
\hline \multirow{2}{*}{ Female } & $17-18$ & - & 5,4 & 23,8 & 6,9 & - \\
\cline { 2 - 7 } & $19-20$ & - & 6,9 & 20,8 & 7,0 & - \\
\cline { 2 - 7 } & $21-22$ & - & 5,4 & 19,2 & 4,6 & - \\
\hline \multicolumn{2}{|c|}{ Total } & - & - & 63,8 & 18,5 & - \\
\hline
\end{tabular}
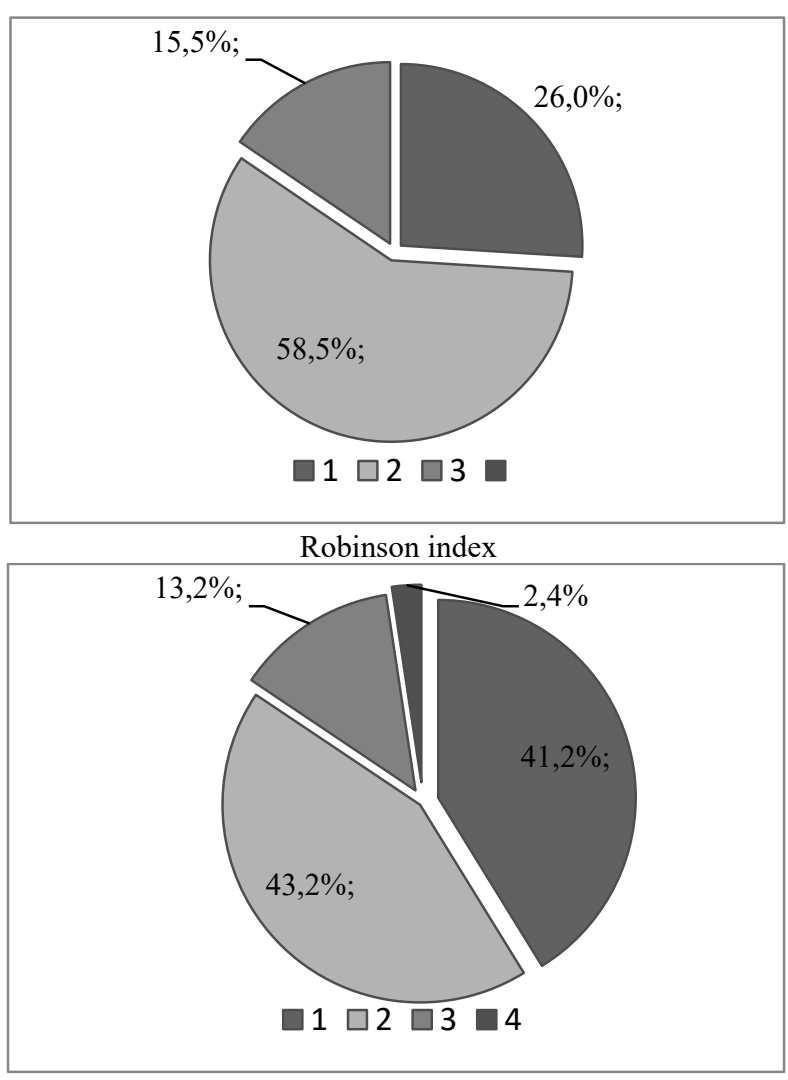

Ruffier index

Fig. 3. Robinson index indicator and Ruffier index indicator by students: 1 - above the average level; 2 - the average level; 3 below the average level; 4 - high level.

Knowing how the values of heart rate and blood pressure change during exercise, it is possible to evaluate the adequacy of the cardiac response to this load and to evaluate the effectiveness of the cardiovascular system as a whole.

There have been no cases of low Ruffier index scores among students, indicating a lack of adaptation reserves and adaptation of the cardiovascular and respiratory systems, which limits the physical capacity of the student body. Students need a significant increase in the daily amount of motor activity.

Therefore, below the average level of recovery time after 20 squats in 30 seconds was identified in $13,2 \%$ of respondents, the average level $-43,2 \%$, above the average $-41,2 \%$, high $-2,4 \%$.

Table 5. The level of the indicator of the recovery time of the functional state of students, $\%$.

\begin{tabular}{|c|c|c|c|c|c|c|}
\hline \multirow[b]{2}{*}{ Sex } & \multirow[b]{2}{*}{ Age } & \multicolumn{5}{|c|}{ Indicator Level } \\
\hline & & Low & \begin{tabular}{|c|} 
Below the \\
average
\end{tabular} & Average & $\begin{array}{c}\text { Above the } \\
\text { average }\end{array}$ & High \\
\hline \multirow{3}{*}{ Male } & $17-18$ & - & 3,3 & 19,2 & 15 & 0,8 \\
\hline & $19-20$ & - & 4,2 & 14,2 & 13,3 & 1,6 \\
\hline & $21-22$ & - & 5,8 & 11,8 & 10 & 0,8 \\
\hline \multicolumn{2}{|c|}{ Total } & - & 13,3 & 45,2 & 38,3 & 3,2 \\
\hline \multirow{3}{*}{ Female } & $17-18$ & - & 6,2 & 11,5 & 16,9 & 1,6 \\
\hline & $19-20$ & - & 2,3 & 17,7 & 14,6 & - \\
\hline & $21-22$ & - & 4,6 & 14,6 & 10 & - \\
\hline \multicolumn{2}{|c|}{ Total } & - & 13,1 & 43,8 & 41,5 & 1,6 \\
\hline
\end{tabular}

Summing up the points accrued for each indicator, a quantitative assessment of the level of health is given (Table 6,7). The higher the score, the better your health.

Table 6. The scale of assessment of the level of physical condition of male students by the method of G. L. Apanasenko [4].

\begin{tabular}{|c|c|c|c|c|c|c|}
\hline \multirow{2}{*}{ Indicator } & \multirow{2}{*}{ Sex } & Low & $\begin{array}{c}\text { Below } \\
\text { the } \\
\text { average }\end{array}$ & Average & $\begin{array}{c}\text { Above } \\
\text { the } \\
\text { average }\end{array}$ & High \\
\hline $\begin{array}{c}\text { Mass-height } \\
\text { index }\end{array}$ & male & $\geq 501$ & $451-500$ & $401-450$ & $375-400$ & $\leq 375$ \\
\hline \multicolumn{2}{|c|}{ Points } & $(-2)$ & $(-1)$ & $(0)$ & $(-1)$ & $(-2)$ \\
\hline Life Index & male & $\leq 50$ & $51-55$ & $56-60$ & $61-65$ & $\geq 66$ \\
\hline \multicolumn{2}{|c|}{ Points } & $(0)$ & $(1)$ & $(2)$ & $(3)$ & $(5)$ \\
\hline Power Index & male & $\leq 60$ & $61-65$ & $66-70$ & $71-79$ & $\geq 80$ \\
\hline \multicolumn{2}{|c|}{ Points } & $(0)$ & $(1)$ & $(2)$ & $(3)$ & $(4)$ \\
\hline $\begin{array}{c}\text { Robinson } \\
\text { Index }\end{array}$ & male & $\geq 111$ & $95-110$ & $85-94$ & $70-84$ & $\leq 69$ \\
\hline \multicolumn{2}{|c|}{ Points } & $(-2)$ & $(0)$ & $(2)$ & $(3)$ & $(4)$ \\
\hline Ruffier Index & male & $\geq 3$ & $2-3$ & $1,3-1,59$ & $1,0-1,29$ & $\leq 1$ \\
\hline \multicolumn{2}{|c|}{ Points } & $(-2)$ & $(1)$ & $(3)$ & $(5)$ & $(7)$ \\
\hline $\begin{array}{c}\text { Overall health } \\
\text { score, points }\end{array}$ & $\leq 4$ & $5-9$ & $10-13$ & $14-15$ & $17-21$ \\
\hline
\end{tabular}

With this rating system, safe health (above average) starts at 14 points. This is the lowest amount of points that guarantees the absence of clinical signs of the disease. Its decline is accompanied by a progressive increase in the number of diseases and a decrease in the body's functional reserves to a dangerous level bordering on pathology. It should be noted that the absence of clinical manifestations of the disease is not yet indicative of stable health. Average level of health can be regarded as critical. Its further decrease already leads to clinical manifestation of diseases $[2,6,7]$.

The average value of the initial assessment of the general level of somatic health of students aged 17-22 years was 11,4 points (Table. 8). This indicator of assessment of the overall level of somatic health, according to the age dynamics of somatic health, is 1,1 points lower than the age norm and corresponds to the norm for the older age group, which indicates an increase in their biological age endurance $[4,6]$. 
Table 7. The scale of assessment of the level of physical condition of female students by the method of G. L. Apanasenko [4].

\begin{tabular}{|c|c|c|c|c|c|c|}
\hline \multirow[b]{2}{*}{ Indicator } & \multirow[b]{2}{*}{$\operatorname{Sex}$} & \multicolumn{5}{|c|}{ Indicators level } \\
\hline & & Low & \begin{tabular}{|c|} 
Below \\
the \\
average
\end{tabular} & Average & $\begin{array}{c}\text { Above } \\
\text { the } \\
\text { average }\end{array}$ & High \\
\hline $\begin{array}{l}\text { Mass-height } \\
\text { index }\end{array}$ & female & $\geq 451$ & $401-450$ & $375-400$ & $400-351$ & $\leq 350$ \\
\hline \multicolumn{2}{|c|}{ Points } & $(-2)$ & $(-1)$ & $(0)$ & $(-1)$ & $(-2)$ \\
\hline Life Index & female & $\leq 40$ & $41-45$ & $46-50$ & $51-56$ & $\geq 57$ \\
\hline \multicolumn{2}{|c|}{ Points } & $(0)$ & (1) & (2) & (3) & $(5)$ \\
\hline $\begin{array}{l}\text { Power } \\
\text { Index }\end{array}$ & female & $\leq 40$ & $41-50$ & $51-55$ & $56-60$ & $\geq 61$ \\
\hline \multicolumn{2}{|c|}{ Points } & $(0)$ & (1) & (2) & (3) & (4) \\
\hline $\begin{array}{l}\text { Robinson } \\
\text { Index }\end{array}$ & female & $\geq$ & $95-110$ & $85-94$ & $70-84$ & $\leq 69$ \\
\hline \multicolumn{2}{|c|}{ Points } & $(-2)$ & $(0)$ & (2) & (3) & (4) \\
\hline $\begin{array}{c}\text { Ruffier } \\
\text { Index }\end{array}$ & female & $\geq 3$ & $2-3$ & $1,3-1,59$ & $1,0-1,29$ & $\leq 1$ \\
\hline \multicolumn{2}{|c|}{ Points } & $(-2)$ & (1) & (3) & (5) & (7) \\
\hline \multicolumn{2}{|c|}{$\begin{array}{l}\text { Overall health } \\
\text { score, points }\end{array}$} & $\leq 4$ & $5-9$ & $10-13$ & $14-15$ & $\begin{array}{l}17- \\
21\end{array}$ \\
\hline
\end{tabular}

Table 8. Assessing the overall level of students' somatic health by G. L. Apanasenko [4]

\begin{tabular}{|c|c|c|}
\hline $\begin{array}{c}\text { Average student } \\
\text { overall somatic health } \\
\text { score, points }\end{array}$ & \multicolumn{2}{|c|}{$\begin{array}{c}\text { Age norm of average values of an } \\
\text { indicator of general somatic health }\end{array}$} \\
\cline { 2 - 3 } & Age & $\begin{array}{c}\text { Assessment of the general } \\
\text { level of somatic health, } \\
\text { points }\end{array}$ \\
\hline \multirow{4}{*}{11,4} & $20-30$ & 12,5 \\
\cline { 2 - 3 } & $31-40$ & 9,2 \\
\cline { 2 - 3 } & $41-50$ & 8,7 \\
\cline { 2 - 3 } & $51-60$ & 6,7 \\
\hline
\end{tabular}

The vast majority of students showed low and below average health level (51,6\% girls and 52,5\% boys). Average health level was observed in $28,3 \%$ of boys and
$36,1 \%$ of girls. Based on the results obtained, it can be argued that the percentage of girls with average health $(7,8 \%)$ is slightly higher than that of boys, but most students still remain outside the safe level (Fig. 4).

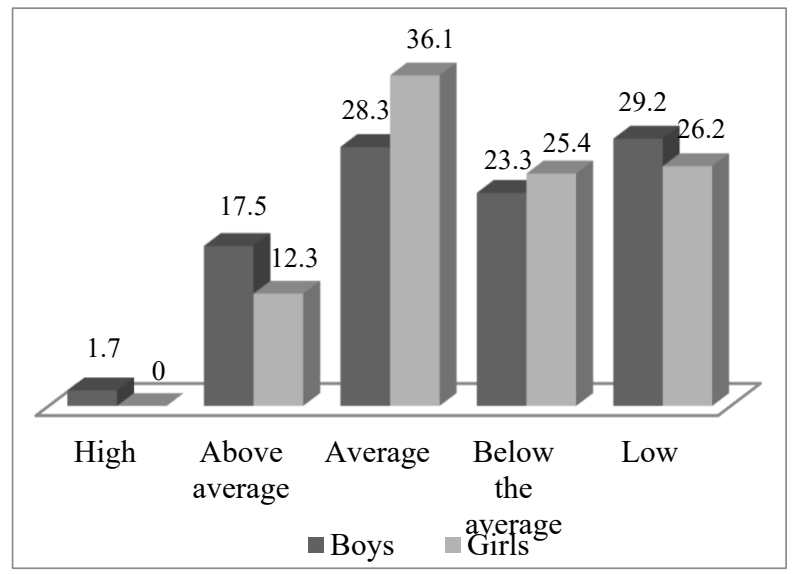

Fig. 4. The ratio of the indictors level of physical state of students of different sex according to the method of G. L. Apanasenko, in \%.

However, one cannot help but see the contradictions between the imaginary state of health and physical fitness and their real indicators.

Comparative analysis of students' self-esteem of health and express assessment by the method of G. L. Apanasenko showed the need for constant monitoring of indicators of physical development and somatic health of students throughout the entire period of study.

Thus, in order to objectively evaluate somatic health and track it in dynamics, the students proposed the information-methodical model of health that was developed by the authors (Fig. 5).

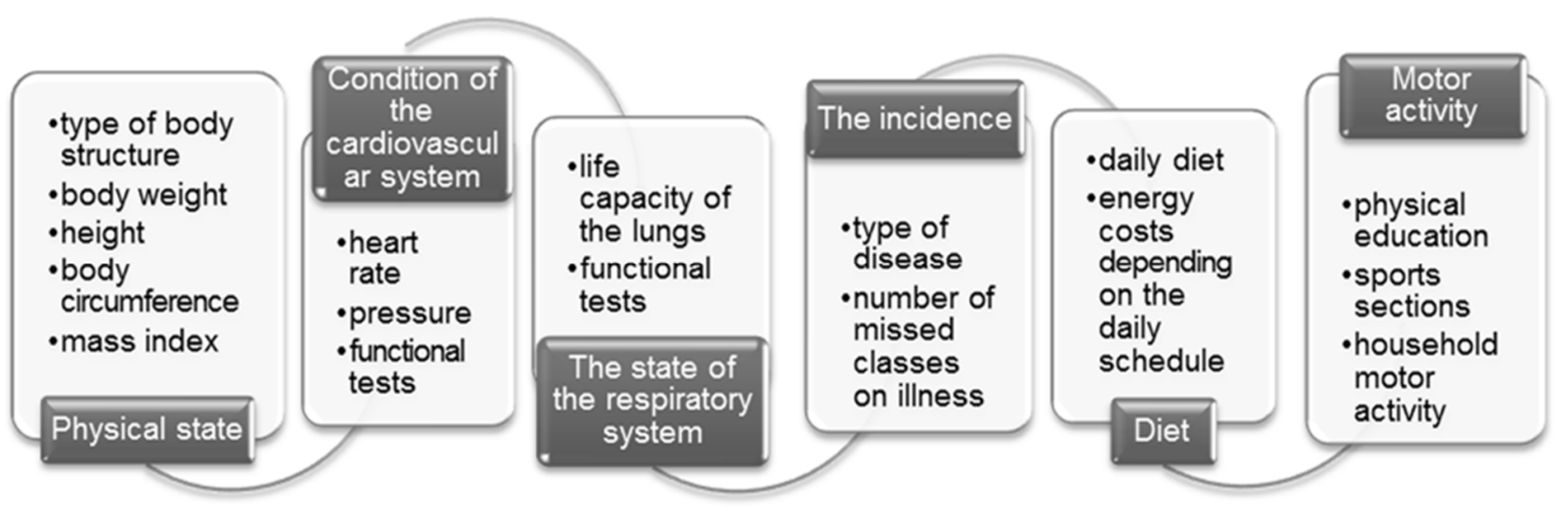

Fig. 5. Model of health.

We have developed an electronic product "Health Portfolio" (Fig. 6), which stores information about the student (name, group, specialization), his data, necessary for calculating health indicators, and monitoring results.

The essence of the program is to provide each student with the opportunity to demonstrate his health potential and sustainable motivation to a healthy lifestyle.
The electronic portfolio allows to enter information about the current state of health, automatically calculate health indicators, visualize the dynamics of changes in health indicators, track the results of work done by the student.

Using the portfolio, the student has the opportunity to conduct an independent analysis of the dynamics of 
changes in his state of health and choose, in accordance with the result, the most suitable way of life for him.

\begin{tabular}{|c|c|c|c|c|}
\hline$\lambda$ & Student & $\stackrel{c}{\text { t Health Pon }}$ & ffolit & $=$ \\
\hline n. & Student & $\frac{t \text { Health Por }}{\text { Training }}$ & tfolio & \\
\hline at & Iyear & II year & III year & N year \\
\hline 34 & Mirzo & oeva Antoni & & \\
\hline s. & Yea & of of birth 200 & & \\
\hline 8 . & & Female & & \\
\hline$n$ & Faculty -C & hemical-bic & ological & \\
\hline$=$ Height, $\mathrm{cm}$ & 179 & 179 & 179 & 179 \\
\hline$=$ Weight, $\mathrm{kg}$ & 56 & 56 & 58 & 60 \\
\hline $\begin{array}{l}\text { Heart rate, } \\
20 \text { beats } / \mathrm{min}\end{array}$ & 80 & 79 & 74 & 75 \\
\hline $\begin{array}{l}\text { Systolic } \\
\text { pressure, mm } \\
\text { 21 of mercury }\end{array}$ & 102 & 102 & 104 & 102 \\
\hline $\begin{array}{l}\text { Diastolic } \\
\text { pressure, mm } \\
\text { nof mercury }\end{array}$ & 72 & 73 & 78 & 70 \\
\hline $\begin{array}{l}\text { Pulse } \\
\text { pressure, mm } \\
\text { wof mercury }\end{array}$ & 30 & 29 & 26 & 30 \\
\hline $\begin{array}{l}\text { Static } \\
\text { balancing, } \\
\text { sec. }\end{array}$ & 60 & 60 & 60 & 60 \\
\hline $\begin{array}{l}\text { Ruffier } \\
\approx \text { sample, units }\end{array}$ & \begin{tabular}{|c|}
10 \\
Satisfactorily \\
\end{tabular} & 11 Weak & 11 Weak & 13 Weak \\
\hline $\begin{array}{l}\text { Vital capacity } \\
\text { of the lungs, } \\
\end{array}$ & 3300 & 3300 & 3400 & 3400 \\
\hline $\begin{array}{l}\text { Dynamometer } \\
n \text { indicator, } \mathrm{kg}\end{array}$ & 31 & 30 & 30 & 33 \\
\hline $\begin{array}{l}\text { Overall health } \\
\text { score }\end{array}$ & 7 Average & 8 Average & 9 Average & 9 Average \\
\hline$\approx$ Health group & preparatory & preparatory & preparatory & preparatory \\
\hline
\end{tabular}

Fig. 6. "Health Portfolio".

This software product allows to individualize the process of changing the physical state of student youth, as well as to form a stable motivational and value attitude to their health.

\section{Conclusions}

Express-estimation of somatic health level determination according to G. L. Apanasenko method showed that students had lower than average and low levels of somatic health.

Considering the results of the research, it is possible to state in general about unsatisfactory health state of student youth, which confirms the necessity to introduce and use the developed electronic product "Health Portfolio". Visualization of indicators of physical health, as well as the annual correlation of its indicators will encourage the student youth to reconsider their lifestyle, to be more attentive to their health.

Information-communication technologies are an effective source of promotion of healthy lifestyles among young people in order to gain professional competence and competitiveness of future professionals.

\section{References}

1. T. Stanishevskaya, O. Gornaya, D. Gorban, A. Berezhnyak, Daily dynamics of blood microcirculation indices in female students. Ped., psych. and meth.-biol. problems of phys. educ. and $\begin{array}{llll}\text { sport } & 6, & 23-29 & \text { (2015). }\end{array}$ doi:10.15561/18189172.2015.0604

2. S. Futorny, Health-saving technologies in the process of physical education of student youth (Summit Book, Kyiv, 2014)
3. L. Dolzhenko, Nat. Uni. of Phys. educ. and sports 3, 22 (2007)

4. G. Apanasenko, L. Popova, A. Maglovani, Sanology (medical aspects of valeology): a textbook for physicians-students of institutions (faculties) of postgraduate education (Kvart, Lviv, 2011)

5. T. Efremova, E. Volkova, Educ. and train.: theory, meth. and pract. 1, 326-328 (2015).

6. G. Apanasenko, V. Gavrilyuk, Biological degradation of Homo sapiens: ways of counteracting (Palmarium acad. publ., Saarbrucken, 2014)

7. Y. Maksimova, Monitoring of the state of somatic health of students of the first courses of higher educational institutions of Kharkiv. Internauca 7(29), 30-34 (2017). doi:10.24919/2308-4634.2019.163117

8. T. Krutsevych, Theory and Methodology of Physical education (Olimpiyska literature, Kyiv, 2012)

9. O. Kuts, The newest technologies for health promotion of student youth: manual for teachers of phys. culture (Ukr. technologies, Lviv, 2003)

10. V. Gavrylyuk, Individual health in search system assessment. Med. Informat. and Engin. 3, 56-61 (2016). doi:10.11603/mie.1996-1960.2016.3.6754 